\title{
有痛性外脛骨に対する新しい試み
}

\author{
藤 原 稔 史* 白仁田厚*
}

\section{A New Trial for Treatment of Symptomatic Accessory Navicular}

\author{
Toshifumi Fujiwara* and Atsushi Shiranita*
}

【対象】 5 例 5 足（男性 2 例女性 3 例）で, 手術時年齢は平均 14.2 歳（11 17 歳）, 全例 Veitch 分類 の type 2 , 術後経過観察期間は平均 6.8 ケ月（3 ケ月〜 1 年）であった. 【方法】 小皮切にて径 $1.5 \mathrm{~mm}$ の K-wireによる Drilling を行い, 径 $1.5 \mathrm{~mm}$ の PLLA thread pin 1 本で固定した. 後療法は術後 1 週 で歩行ギプス固定にて荷重開始，3〜4 週で ROM 訓練開始，4〜5週で全荷重歩行，6〜10 週間でスポー ツ復帰を許可した。【結果】疼痛消失期間は平均 4.4 週 (3〜8 週), スポーツ復帰可能は 4 例中 3 例, 骨性瘑合は 4 例であった。立位 X 線側面像で Méary 角は術後 3 ケ月で 4 例に増加をみたが，有意差はな かった。【考察】Drilling に抜釷不要である PLLA ピンを併用することで骨性瘾合率の向上と, 10 代前 半のみでなく 10 代後半にも骨性癒合が期待できる有用な方法と考えられた.

We report a new surgical treatment based on osteosynthesis for symptomatic accessory navicular. We surgically treated five cases of symptomatic accessory navicular between 2002 and 2003. The average age at the time of surgery was 14 years, and the average follow-up period was 6.4 months. All cases were classified as Veitch type 2.

The surgical method was drilling to the symptomatic accessory navicular by a $1.5 \mathrm{~mm}$ Kirschner wire and fixation by a $1.5 \mathrm{~mm}$ PLLA thread pin. Post-operative treatment was weight bearing in a plaster cast for three to four weeks, and then exercise in the ankle range of motion. The average period to disappearance of foot pain after operation was six weeks.

Key words : symptomatic accessory navicular bone (有痛性外脛骨), surgical treatment (手術療 法), drilling (ドリリング), PLLA pin (ポリーLー乳酸ピン), sports（スポーツ）

は じめに

足部の過剰骨の中で疼痛発生頻度が高い外脛骨 (accessory navicular bone) は, 手術を含めた様々 な治療方法が行われている. 特にスポーツ活動の盛ん な思春期に対しては, 短期間で確実な除痛治療が必要 となる。

今回我々は早期疼痛改善と骨癒合をより確実にし, 早期スポーツ復帰を目的として drilling に生体内吸 収性ポリーL一乳酸骨接合材 (PLLA pin) ${ }^{4) 10)}$ を併用 した方法を行ったので, その有用性について報告す る.

\section{対象および方法}

対象は 2002 年 3 月〜2003 年 6 月までに有痛性外脛 骨に対し手術を行つた 5 例 5 足で, 男性 2 例女性 3 例, 手術時年齢は 11 歳 17 歳 (平均 14.2 歳), 発症原因 にスポーツが関与していた症例は 4 例 (80\%) で，ス ポーツの内容は, 剣道 1 例, バレーボール 2 例, バス ケットボール 1 例であった。単純 X 線上, 全例 Veitch 分類 ${ }^{11)}$ の type II であつた. 罹患期間は 6 ケ月〜 5 年 (平均 2.5 年), 保存療法として, アーチサポー ト装着, スポーツ活動中止による安静を行った。アー チサポートは有痛性外脛骨患者の場合, Leg-Heel Alignment $^{8)}$ を見ると, 扁平足を合併し ${ }^{18)}$, 後足部が 外反していることが多いため, その程度に応じて内側

\footnotetext{
* 九州労災病院整形外科 Department of Orthopaedic Surgery, Kyushu Rosai Hospital, Fukuoka, Japan
} 
ヒールウェッジを加えて使用した.

手術方法は腰椎麻酔下に後脛骨筋付着部に数 $\mathrm{mm}$ の小切開を加え, 後脛骨筋腱を分けて外脛骨に達し, 直径 $1.5 \mathrm{~mm}$ の K-wire を用いてイメージ下に多方向 に 10 ケ所前後 drilling を行い, 最後に直径 $1.5 \mathrm{~mm}$ の PLLA thread pin 1 本を中心部に刺入し固定する. pin が後脛骨筋腱を刺激しないように，外脛骨内に完 全に埋没させる。術後は軽度底屈内反位で 1 週間シー ネ固定とした.

後療法は, 術後 1 週より歩行ギプスによる荷重歩行 を開始させ， $3 \sim 4$ 週間でギプス除去の上，足部の $\mathrm{ROM}$ 訓練を開始, 術後 $4 \sim 5$ 週で全荷重歩行, 6 〜 10 週でスポーツ復帰を許可した.

術後の追跡期間は 3 ケ月〜 1 年（平均 6.4 ケ月）で あった。

$$
\text { 結果 }
$$

疼痛消失期間は 4 例が 4 週以内であった。 スポーツ 復帰は 3 例 $(75 \%)$ が可能となり，1例は術後，術前 と異なる痛みを生じたため，不可となった。骨性癒 合は 4 例に認められた（表 1)。Méary 角 ${ }^{9}$ は術前 $-14.2^{\circ}$ から術後 3 ケ月で $-12.2^{\circ}$ と, paired t-検定で 有意差を認めなかった（ $\mathrm{p}=0.089 ）$ が，軽度改善傾向 を示した（表 2).

\section{症例}

症例 $1: 15$ 歳男性, 剣道

12 歳より左足内側部痛出現し，アーチサポート装 着で疼痛改善しないため, 手術施行, 術後 4 週間ギプ ス固定をした。 ギプス除去時には疼痛は無く, 術後 6 週より全荷重歩行とし, 10 週目でスポーツ復帰した. 単純 $\mathrm{X}$ 線上，術後 3 ケ月で骨癒合が認められた（図
1).

症例 2:11歳女性, バレーボール

11 歳より右足内側部痛出現し，スポーツ中止，アー チサポート装着したが，疼痛は消失せず，手術を施行 した，術前の CT で外脛骨－舟状骨間が不整であり， 骨シンチで患側の外脛骨に軽度の集積像を認めた.

術後 3 週間ギプス固定を行い, ギプス除去時には疼 痛は消失したが，翌週に新たな右足部痛が出現した。 単純 X 線上，術後 3 ケ月で骨癒合認めたが，新たな 遊離骨片を認め, この骨片と疼痛部位とは一致してい た. 術後 8 ケ月経過しても遊離骨片部位の疼痛は持続 していた（図 2).

症例 5:15 歳女性, バスケットボール

14 歳より右足部痛出現し, 早期スポーツ復帰を希 望したため, 手術を施行した。 術前, CT 上, 外脛骨一 舟状骨間は不整像を呈し，骨シンチで患側外脛骨部に 集積像を認めた。 術後 3 週間ギプス固定を行い, ギプ ス除去時には右足部痛は消失した。術後 6 週間でスポー ツ復帰を許可したが，許可直後より，激しいスポーツ 活動を行った。単純 X 線上，術後 3 ケ月で骨癒合は 明らかでなく，5ケ月経過後も，骨癒合を認めなかっ た。また，時々歩行時に疼痛を生じた（図 3).

表 2 術前, 術後 3 ケ月の Méary 角 $(\mathrm{p}=0.089)$

\begin{tabular}{|c|c|c|c|}
\hline 症例 & 術前 & Méary 角 & 術後 3 ケ月 Méary 角 \\
\hline 1 & & -6 & -1 \\
\hline 2 & & -25 & -24 \\
\hline 3 & & -18 & -15 \\
\hline 4 & & -14 & -14 \\
\hline 5 & & -8 & -7 \\
\hline 平均 & & -14.2 & -12.2 \\
\hline
\end{tabular}

表 1 症例一覧

\begin{tabular}{|c|c|c|c|c|c|c|c|c|c|c|}
\hline 症例 & 年齢・性 & 患側 & スポーツ種目 & type & $\begin{array}{l}\text { 術前罹患 } \\
\text { 期間(年) }\end{array}$ & $\begin{array}{c}\text { ギプス固定 } \\
\text { 期間 (週) }\end{array}$ & $\begin{array}{l}\text { 疼痛消失 } \\
\text { 時期 (週) }\end{array}$ & $\begin{array}{l}\text { 全 荷 重 } \\
\text { 時期 (週) }\end{array}$ & $\begin{array}{c}\text { スポーツ復帰 } \\
\text { 時期 (週) }\end{array}$ & $\begin{array}{l}\text { 骨癒合の有無 } \\
\text { (術後 } 3 \text { ケ月) }\end{array}$ \\
\hline 1 & 15·男 & 左 & 剣道 & II & 3 & 4 & 4 & 6 & 10 & + \\
\hline 2 & $11 \cdot$ 女 & 右 & バレーボール & II & 0.5 & 3 & 3 & 4 & 不可 & + \\
\hline 3 & $13 \cdot$-女 & 左 & & II & 3 & 3 & 4 & 4 & & + \\
\hline 4 & 17·男 & 左 & バレーボール & II & 5 & 4 & 8 & 4 & 8 & + \\
\hline 5 & $15 \cdot$ 女 & 右 & バスケットボール & II & 1 & 3 & 3 & 4 & 6 & - \\
\hline 平均 & 14.2 & & & & 2.4 & 3.4 & 4.4 & 4.4 & & $4 / 5$ 例 \\
\hline
\end{tabular}




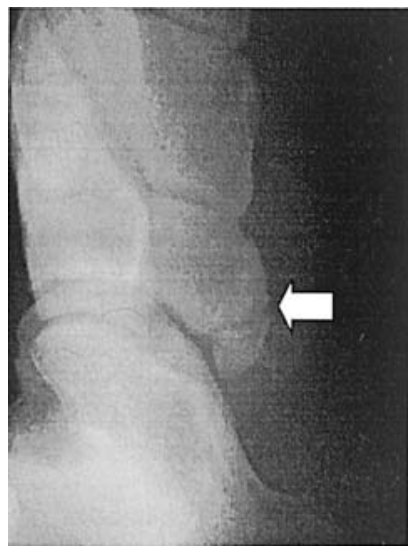

$\mathrm{a}:$ 術前

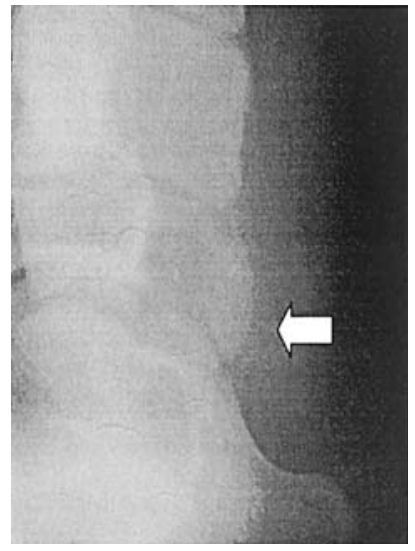

$\mathrm{b}:$ 術後 3 ケ月

図 1 症例 115 歳男性（患側：左） 術後 3 ケ月で骨癒合が認められた。

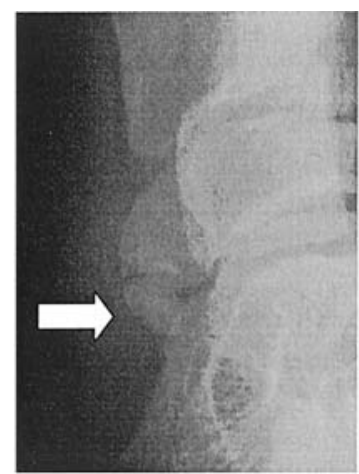

$\mathrm{a}$ : 術前

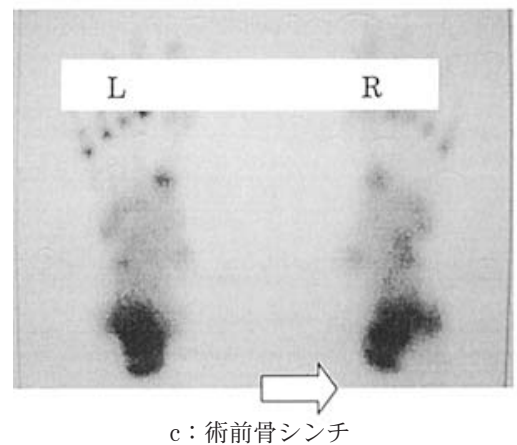

図 2 症例 211 歳女性（患側：右）

術前の骨シンチで幹部に軽度の集積像を認め, CT で舟状骨と外脛骨との間が不整 であった，術後 3 ケ月後の CT で外脛骨と舟状骨は骨癒合を認めたが，微小の遊離 骨片を認めた。

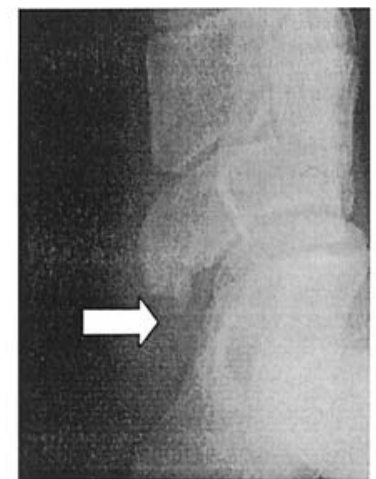

$\mathrm{b}:$ 術後 3 ケ月

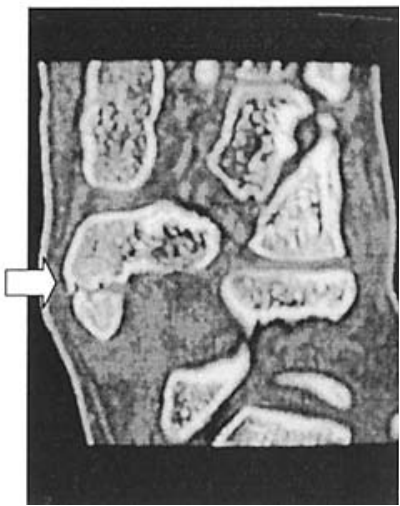

$d ：$ 術前 CT 


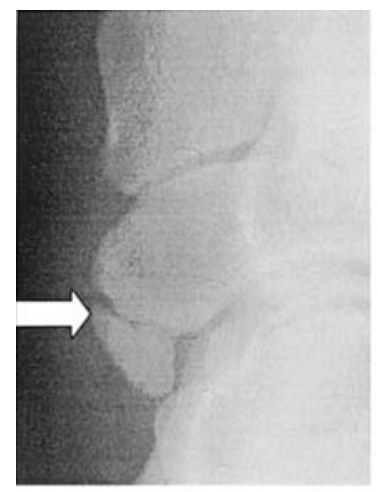

$\mathrm{a}:$ 術前

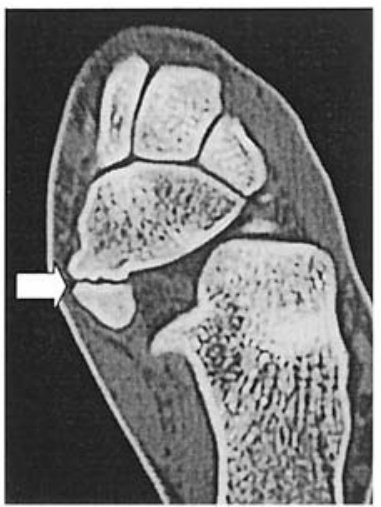

c：術前 CT

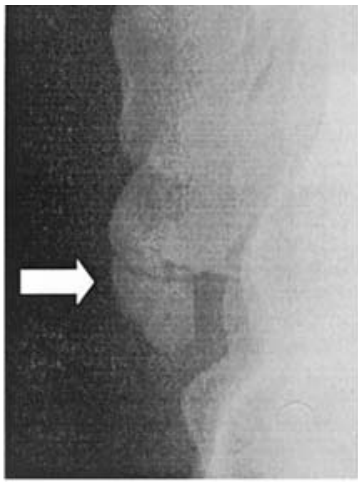

$\mathrm{b}:$ 術後 3 ケ月

L

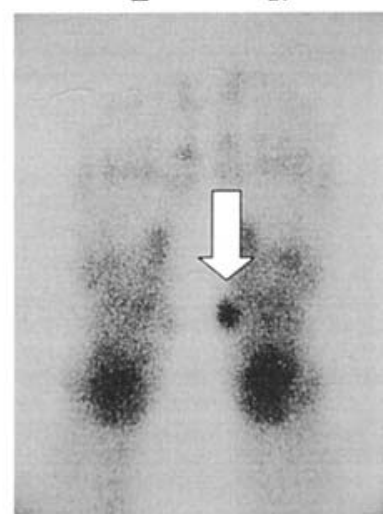

d : 術前骨シンチ

図 3 症例 515 歳女性（患側：右）

術前の CT で舟状骨と外脛骨の間が不整であり, 骨シンチで患部に集積像を認めた. 術後 3 ケ月で骨癒合は得られていなかった.

考 察

有痛性外脛骨の治療はまず，局所安静や消炎鎮痛剂 の投与, 足底板の装着といつた保存的治療を行う。し かし, 疼痛の持続や再発で, スポーツ活動が長期間制 限される場合には手術療法を選択する.

有痛性外脛骨の手術療法として, drilling, 単純摘 出術，骨接合術などが報告されている．当院では過去 に単純摘出術を主体に手術療法を行つてきたが, 成績 が安定しなかったため，骨接合を目的として drilling にPLLA pin 固定を併用した方法を行った.

平本らが当院の有痛性外脛骨に対して行った治療成 績 (単純摘出術とdrilling) ${ }^{2)}$ と今回の方法を比較す
ると, 症例数は少ないが運動時疼痛消失までの期間の 短縮が認められた（図 4)。単純摘出術は個々の症例 により疼痛改善時期に差が多く, 治療成績が安定しな いという報告がある(7)9). 一方，中山らによると， drilling は早期疼痛改善が得られるが, 骨性癒合は $72 \%$ で，骨癒合の期待は 10 歳前半に限定されると報 告した ${ }^{67)}$. drilling の利点は早期疼痛改善, 低侵襲, 骨癒合が可能(6)7 という点である。ささら生体内吸収 材料である PLLA pin を併用し外脛骨を固定するこ とで，早期除痛及び骨性癒合率を向上させ，10 代後 半にも骨癒合を可能にすると考えられる，骨癒合可能 例は Veitch 分類 type II で CT 上結合部が不整で，か つ骨シンチで, Hot Spotを示す症例であると我々は 
a

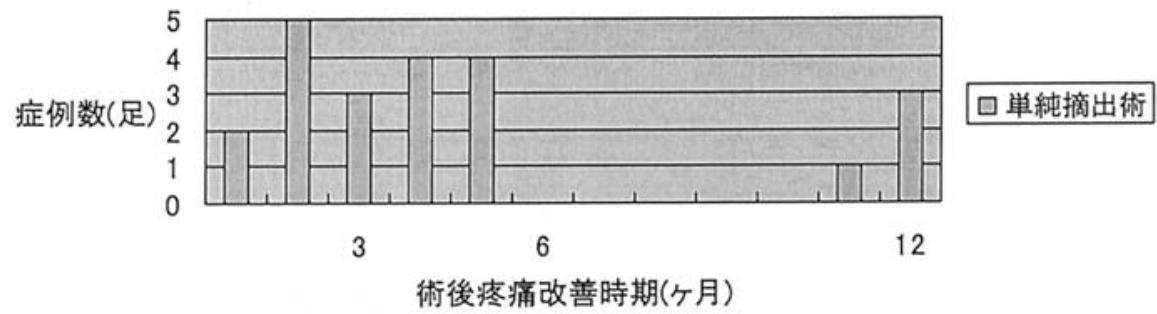

b

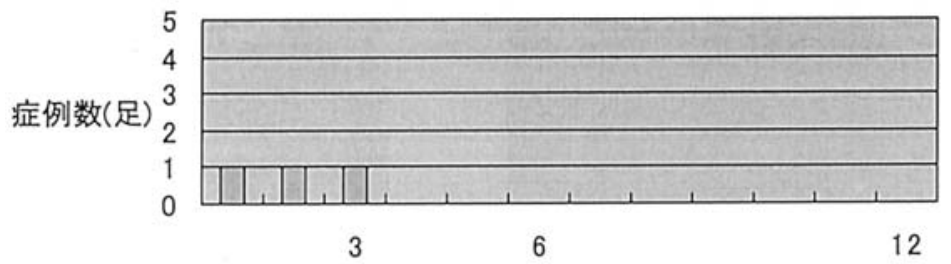

$\square$ Drilling

術後疼痛改善時期(ケ月)

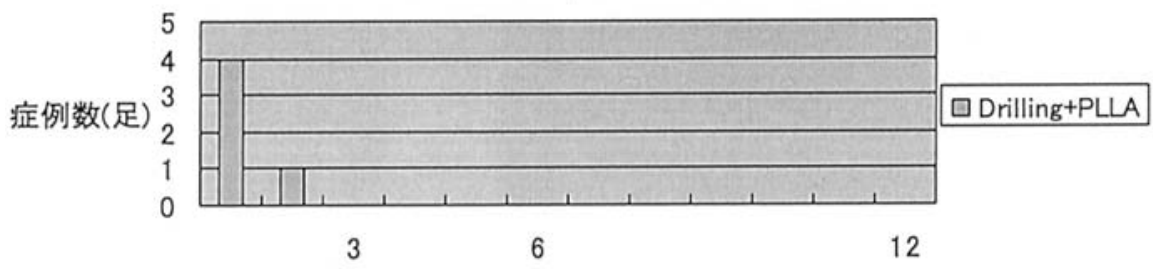

術後疼痛改善時期(ケ月)

図 4 当院で行ったそれぞれの術式の術後疼痛改善時期 $\mathrm{a}$ : 単純摘出術 (22 足)

$\mathrm{b}$ : Drilling 単独（3 足）

c: Drilling + PLLA pin (5 足)

単純摘出術や Drilling 単独に比べ, Drilling + PLLA pin では明らかに運動時痛消 失までの期間は短縮された。

考えている (図 5).

他の骨接合法として, ワイヤー固定 ${ }^{3)}$, Cannulated Screw 固定 ${ }^{9}$, Herbert Screw 固定 ${ }^{8)}$ がある（表 3). 骨癒合の成績は良好であるが，全て外脛骨の関節面を 切除, 新鮮化することを必要としており, その手術侵 襲は大きく，抜釘が必要な点も問題である．我々の方 法はin situ fixationができるという点でも他の方法 より侵襲が小さく試みられてよい方法と考えている.

今後の課題として, 症例 2 は 11 歳と若く, drilling の際，外脛骨が柔らかく感じられ，術中操作の際，骨 片が遊離された可能性があった。手技的問題と考えら
れ，特に骨成熟の幼弱な年齢での手術には慎重を要す ると考えられる. PLLA pin は無菌性炎症反応を起 こすという報告 ${ }^{410)}$ があり，危惧しているが，現在 1 例も認めていない. また挿入固定時の折損の可能性も あるため, 慎重な手術手技が必要である. drilling 後 にPLLA pin で固定するため，ギプス固定期間や全 荷重時期を早めることも考えている. しかし， スポー ツ復帰時期を早めると骨癒合が得られなくなってしま う可能性も示唆されたため, 個々の症例で対応すべき であろう。 CT, 骨シンチでの評価により，成人例へ の適応拡大の可能性がある. 今後, さらに症例を重ね 
L

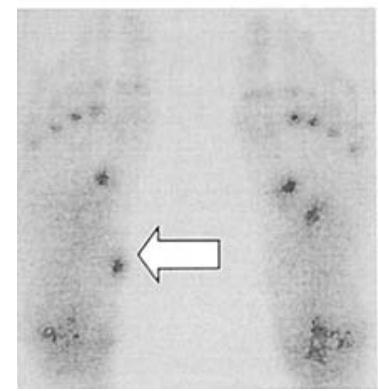

a : 骨シンチ
$\mathrm{L}$

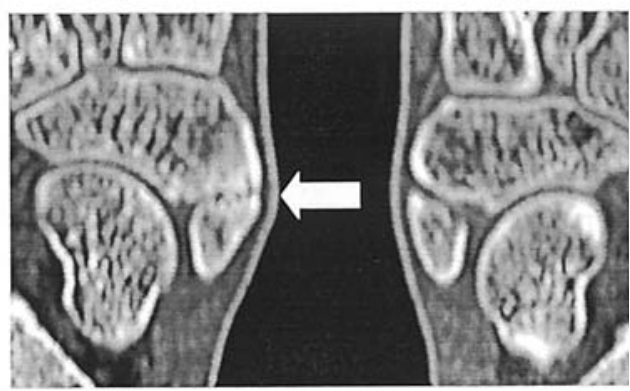

$\mathrm{b}: \mathrm{CT}$

図 5 骨癒合可能例 (患側 : 左)

骨シンチで患側に Hot Spotを示す．CT で健側と比較してみると, 患側の結合面 が不整である.

表 3 骨接合法の比較

\begin{tabular}{|c|c|c|c|c|}
\hline 骨接合法 & 症例数 (足) & 骨癒合率 (\%) & 外固定期間 (週) & 合併症（足） \\
\hline ワイヤー固定 ${ }^{3)}$ & 12 & $83(10 / 12)$ & 6 & ワイヤー折損 (2) \\
\hline Cannulated Screw 固定 ${ }^{9)}$ & 38 & $100(38 / 38)$ & 5 & $(-)$ \\
\hline Herbert Screw 固定 ${ }^{8)}$ & 5 & $100(5 / 5)$ & 3 & $(-)$ \\
\hline drilling + PLLA pin & 5 & $80(4 / 5)$ & $3 \sim 4$ & $(-)$ \\
\hline
\end{tabular}

ていきたいと考えている.

$$
\text { ま と め }
$$

(1) 5 例 5 足の有痛性外脛骨に対し, drillingに PLLA pin 固定を併用した治療法の短期成績を検討 した.

(2)疼痛の改善は単純摘出術や drilling 単独よりも 早期に得られた.

(3)術後 3 ケ月で骨性癒合は $80 \%$ に認めた.

(4)本法は外脛骨の骨性癒合率を高める可能性がある 低侵襲な手術法と思われた.

\section{参 考 文 献}

1) 羽鳥正仁ら：偏平足. 関節外科, 16 (6) : 79-85, 1997.

2）平本貴義ら：有痛性外脛骨の手術療法と治療成績. 日 足外会誌, $23(2): 145-148,2002$.

3）木谷武志，辻井 潔 : 有痛性外脛骨症の骨接合術. 手
術, $9:$ 1225-1229, 1986.

4）松末吉隆，中村孝志：吸収性材料 PLLA. 関節外科, 17 (1) : 39-45, 1998.

5) Méary, R.: On the measurement of the angle between the talus and the first meta-tarsal. Le Pied Creux Essentiel. Rev. Chir. Orthop., 11 : 85, 1958.

6) 中山正一郎, 高倉義典 : 疼痛性外脛骨症. 関節外科, $16(6)$ : 86-92, 1997.

7）中山正一郎, 高倉義典 : 疼痛性外脛骨症の手術的治療. 整形外科別冊, $25: 125-129,1994$.

8）岡村良久, 原田征行 : 有痛性外脛骨の診断と治療. 骨 関節・勒带, 6(9) : 1031-1038, 1993.

9）大塚健一ら：小児における疼痛性外脛骨の手術成績. 日小整会誌, $10(2) ： 117-120,2001$.

10）敷波保夫：生体材料としてのポリ乳酸の特性と応用. リウマチ科, 21(3) : 267-278, 1999.

11) Veitch, J. M.: Evaluation of the Kidner procedure in treatment of symptomatic accessory tarsal scaphoid. Clin. Orthop., 131 : 210-213, 1978. 